Meta

Journal des traducteurs

Translators' Journal

\title{
The Paris Arcades, the Ponte Vecchio and the Comma of Translation
}

\section{Sherry Simon}

Volume 45, numéro 1, avril 2000

La traduction littéraire au Canada

Literary Translation in Canada

URI : https://id.erudit.org/iderudit/004150ar

DOI : https://doi.org/10.7202/004150ar

Aller au sommaire du numéro

Éditeur(s)

Les Presses de l'Université de Montréal

ISSN

0026-0452 (imprimé)

1492-1421 (numérique)

Découvrir la revue

Citer cet article

Simon, S. (2000). The Paris Arcades, the Ponte Vecchio and the Comma of Translation. Meta, 45(1), 73-79. https://doi.org/10.7202/004150ar
Résumé de l'article

Cet article soutient que la traduction littéraire canadienne donne de l'ampleur à ses mandats culturels et esthétiques. Lorsque, dans les années 1970, Philip Stratford nommait les traductions de la littérature québécoise des "nouvelles du front ", il faisait référence au rôle journalistique des traducteurs. d'utilisation que vous pouvez consulter en ligne.

https://apropos.erudit.org/fr/usagers/politique-dutilisation/ 


\title{
The Paris Arcades, the Ponte Vecchio and the Comma of Translation
}

\author{
SHERRY SIMON \\ Concordia University
}

\begin{abstract}
RÉSUMÉ
Cet article soutient que la traduction littéraire canadienne donne de l'ampleur à ses mandats culturels et esthétiques. Lorsque, dans les années 1970, Philip Stratford nommait les traductions de la littérature québécoise des «nouvelles du front», il faisait référence au rôle journalistique des traducteurs.
\end{abstract}

\begin{abstract} crossroads of sensibilities.

\section{MOTS-CLÉS/KEYWORDS}

Walter Benjamin, hybridation, literary translation, mediation, links
\end{abstract}

This article argues that Canadian literary translation is enlarging its cultural and esthetic mandates. When Philip Stratford in the 1970 s called translations of Quebec literature 'news from the front,' he was referring to the journalistic role played by translators in transmitting Quebec literary news. Rather than acting exclusively as mediators, writer/ translators are now increasingly involved in creating hybrid literary texts informed by a double culture. The novels of Gail Scott, the 'renga' of Jacques Brault and E.D. Blodgett are examples of such texts. They use languages to cross traditions, making their texts a

Gail Scott's latest novel, My Paris, contains a device which she calls "the comma of translation." This comma is something of an intruder in a book which is "imbued with the ghost of Gertrude Stein" (p. 163) and with her opinions on language. Gertrude Stein banished the comma from modernist writing and indeed My Paris is written in a rigorously crafted modernist style, made up of sentence fragments separated by periods. ${ }^{1}$ But Scott does use a few commas. These occur when the narrator uses a French expression which is followed by its translation. For instance, "mal foutue, badly shoed" (p. 18) or the lyrics of a song, "Nous sommes les animaux," "we are animals" (p. 72). About a third of the way into the novel, the narrator seems to provide an explanation. Evoking Stein's dictum against commas, she wonders: "But if comma of translation disappearing. What of French-speaking America remaining" (p. 49).

Scott's comma of translation draws us into a rich web of thinking about language and translation which leads us from Paris to Montreal, from Gertrude Stein and Walter Benjamin to experimental writing in Quebec, from the modernist experience of expatriation to the postmodern reality of cultural hybridity. By posting signs of cultural difference, Scott is revising the modernist illusion of a nude and value-free formalism, its desire for universality. By placing translation within her novel, Scott is pointing towards a space which holds increasing significance in the contemporary world: the space where multiple languages gather, where translation and writing express the same impulse to use language contact creatively. 
I would like to explore some of the connections created by the "comma of translation," connections that draw translation and writing together. These links will extend in two directions, towards the literary project of a writer/translator like Gail Scott who expresses the tensions of a multilingual Montreal (and in particular those anglophone writers who write out of the dissonances and marginalities of their situation) and towards the poetic dialogue which Jacques Brault and E. D. Blodgett have created in Transfiguration.

In both cases, I would like to emphasize a shift in the mandate which Canadian translation seems to be giving itself. When Philip Stratford in the 1970s called translations of Quebec literature "news from the front," he was referring to an intense flurry of exchange between Quebec and English Canadian literature, an exchange motivated by curiosity and fascination. Translators were called upon to "transmit" Quebec literary news to new readers. The informative and ambassadorial role, I would argue, is now being augmented by another dimension. Rather than acting exclusively as mediators, writer/translators are increasingly involved in creating hybrid literary texts which are informed by a double culture. The novels of Gail Scott, the "renga" of Brault and Blodgett are examples of such texts. They use languages to cross traditions, making their texts a crossroads of sensibilities.

\section{The Arcades of Paris}

The many allusions in My Paris to Gertrude Stein-and also to Walter Benjaminremind us that Paris at the turn of the century was the capital of modernism and a cosmopolitan centre for expatriate writers and artists. For many, if not all of the English-language writers who lived in Paris, the experience of expatriation itself was at the heart of modernist rethinking of literary norms. "Translation" stands for a whole array of practices through which modernists used other languages and traditions for esthetic innovation. These crossovers were not always made visible, however. The exceptional cases were the deviant and eccentric forms of trans-lingual writing conceived by Pound, Beckett and Joyce. For most of the other writers, however, translation was much more of an implicit practice, in the sense, for instance, in which it was said that Mina Loy, "transferred futuristic theories to America," "translating" into English the aesthetics of Apollinaire and Marinetti" (Burke: 5).

Scott chooses to repair this omission, to restore visibility to translation by defying Stein's prohibition against commas and by placing the French language within her text. While My Paris is a work which renders homage to the audacity of modernism, and to the complexity of Gertrude Stein's rethinking of language, the novel at the same time takes its distance from some of Stein's practices and assumptions. In particular, Scott draws attention to cultural difference, critiquing Stein's position in the modernist negotiation of literary identities, giving visibility to the French language, making explicit and present the language through which Stein designed and rethought her poetics.

But there is a second mythical presence in My Paris which intensifies the significance of translation in the novel. This presence is Walter Benjamin, whose Passagenwerk (the Arcades project) appears as a recurrent reference. This huge and unfinished project by Benjamin is a vast collection of notes on 19th-century industrial culture as it took place in Paris. Benjamin's experience of Paris, we recall, is strongly coloured 
by the spirit of Baudelaire, whose work, Tableaux parisiens, Benjamin himself translated into German. The preface to that translation, entitled "The Task of the Translator," has become a signal essay on translation, a dense and ambiguous text, which has lent itself to innumerable interpretations and commentaries.

The "comma of translation" leads us directly to Benjamin's reinterpretation of the role of translation. Benjamin's essay is extraordinarily rich and complex, and can hardly be summarized in a few sentences. The following remarks, therefore, run the risk of extreme oversimplification. ${ }^{2}$ One of the central points of Benjamin's argument is that translation is less about transmitting a message than it is about revealing differences. The task of the translator, he suggests, is not to neutralize the difference between the original and the translation through the replacement of one with the other, but to display the complementarity of languages and texts. The space between one language and another suggests a "third space" between original and translation, a utopian space that no longer means or expresses anything, but refers to a "reine Sprache," a pure language, an expressionless and creative Word. Benjamin gives a physical shape to this space: the shape of the arcade. ${ }^{3}$

Benjamin uses the arcade in his later work as a cultural historian to represent an ambiguous urban space, neither inside nor outside, a passageway which is also a space of consumption, a new materialization of urban space. In the essay on translation, he uses the arcade to formulate a contrast between interpretive translation (which uses as its unit the "sentence" or the "proposition") and literal translation (which proceeds word by word). The first, he says, produces a translation akin to a wall, the second a text which functions more like an arcade: "For if the sentence is the wall before the language of the original, literalness is the arcade." 4 The glass roof allows light to flow through matter, just as the literally translated text is a transparent surface which allows the light of the original to fall onto the new version, creating an interplay of surfaces. The literal translation will provide a vision of newness accumulated out of the fragments of words, just as the "literal historian" will use the arcades to write a new kind of history of Paris in the nineteenth century. (Niranjana: 119) Both translator and historian rely on the unexpected encounter of objects and words, the confrontation of languages and temporalities, to jar us into a renewed understanding of the present. The work of translation, like the work of history, provide forms through which the past and present "flash" into uneasy constellation.

The comma of translation points to this disjunctive interplay of surfaces. It can be seen as a pulse-point, drawing the languages together and separating them at the same time, gesturing toward a third term, the space between the "original" and its "afterlife" in a second language. The juxtaposition of English and French phrases across the comma points to translation as a movement which reveals, rather than conceals, difference. The first language does not disappear in favour of the second but persists, like some pesky ghost.

What realms of meaning does the comma point to? My Paris offers a few clues to the way Scott envisions this space. At one point in her novel, Scott's narrator says: "Wanting to stay afloat. To stay out of categories. Moving back and forth. Across comma of difference. A gerund. A gesture" (p. 107). The comma is therefore the space in-between, a space of blurred categories and undecidability. The comma is not a moment of explanation or interpretation ("Avoiding interpretative, i.e. cause-andeffect narrative," (p. 93), but a space in-between, a space of blurred categories and 
undecidability. Here alternatives are suspended, multiple realities come together, differences coexist. This is the space of the act of translation.

Increasingly recognized as a space carrying both "ethical and esthetic imperatives," the act of translation couples dislocation with the renewal of life. Translingual practice points not to abstract ideas of identity and equivalence, but to the "continua of transformation" that mark our experience of language and of history. (Bhabha 1996: 200, 203)

\section{From Paris to Montreal}

As an anglophone writer living in Montreal, Gail Scott lives, as many of us do, "in translation." She gives to this situation, to this consciousness of negotiating across languages and communities, a broad range of meanings: not only the experience of daily existence in a multilingual neighbourhood, or sensitivity to the political battles of French against continental homogenization, but also the desire to affiliate herself with a writing community that gives priority to questions of form and language. ${ }^{5}$ In her essays, Gail Scott has insisted on the influence of francophone writing in her attempts to develop a formally innovative writing style. This language-consciousness and writerly sensibility are shared by writers like Erin Mouré and Robert Mazjels, who draw from their situation as English-language Montreal writers an opportunity to "see" and reshape language.

It is not entirely surprising, then, that all three writers use "langages" in their writing, or that Scott and Mazjels have recently turned to translation. Scott has translated a novel by France Théoret, Laurence, and Mazjels, two novels by France Daigle. In the case of both Scott and Mazjels, the novels they have chosen to translate extend their own esthetic choices. Laurence, for example, though it presents an apparently linear narrative, is quite radical in its form. The manner of recounting is highly unusual and lacking in a conventional point of view; the storyline is interspersed with a kind of authorial commentary, ex cathedra, which is both extremely precise and enigmatic. There is little lyrism in the text, and a constant sense of premature halts, a jerkiness which prevents intimacy with the character. There are many points of confluence, then, between Laurence and My Paris.

For these writers then, translation and writing, though representing discreet activities, fall along a continuum. ${ }^{6}$ Lines of linguistic tension traverse a variety of texts - novels, essays, translations - revealing pressure points where language and cultural difference, concepts of self and otherness, come to expression through modes of translation.

\section{Bird Calligraphy}

In a recent volume of poetry, entitled Transfiguration, poets Jacques Brault and E. D. Blodgett offer a different version of the translation-writing continuum. The slim volume tightens the weave linking poetry with translation, and lifts these practices away from a specific socio-cultural milieu. At the same time, the poets are driven by the same impulses as those which impel the Montreal anglophone writers: the desire to use translation as a link which both joins and separates, which creates new lines of communication, yet reminding us of the distances which made them necessary in the 
first place. Such is the active contradiction that runs through all translation, the pulsing of same within difference, the "strange familiarity," says Jacques Brault, the "voix de l'autre en soi-même" which is also the principle of any creative writing.

Transfiguration is a renga, consisting of a sequence of poems written alternately and translated. That is, the volume begins with a poem written in English by Blodgett and sent to Brault, who then translates the poem into French and creates a new poem "out of" the translated French one which in turn is sent on to Blodgett. This translation dialogue is "a poem invented for one-legged dancers," says Blodgett in his prefatory note. "Each dancer must surrender to the other to create the figure that the dance, not the dancers, requires." The dancers, as they create the dance, are also possessed by it. Brault's prefatory note also suggests how each participant in the "serious game, undertaken in all innocence" is transformed by the experience. And he concludes, using language which is familiar from his Poèmes des quatres côtés, "Si la poésie est aussi la voix de l'autre en soi-même, alors ce petit livre constitue peutêtre, et à maints égards, une transfiguration."

The volume is remarkable for its unity of tone. Less a clash of musics than a gentle harmonization, the poems are striking in that they can evoke-across linguistic and climactic differences, Brault's Quebec and Blodgett's Alberta-a single landscape of seasons. The poems seem to take their breaths in the same places, to move to the same rhythm. Here translation is not the shock of diversity but rather a sameness dripping like sand with slow elegance through the glass of language. The landscape of marshland moves through languages as it does through seasons, from the dry sun of summer, bees and larks, through fall and winter, to the return of dawn, spring and the bees. Barely do we notice Blodgett's predilection for musical terms, Brault's taste for the asperities of language, obscure terms and words which draw attention to themselves.

The fit between the 'original' and the translation (the 'original' already a product of translation) is elastic, like a sweater passed from a lithe and trim body to a bulky one. In the following example, the English translation "reveals" the text in a way that enlarges it, expands its contour, and making the wind sing a "blue note" which would have been impossible in French...

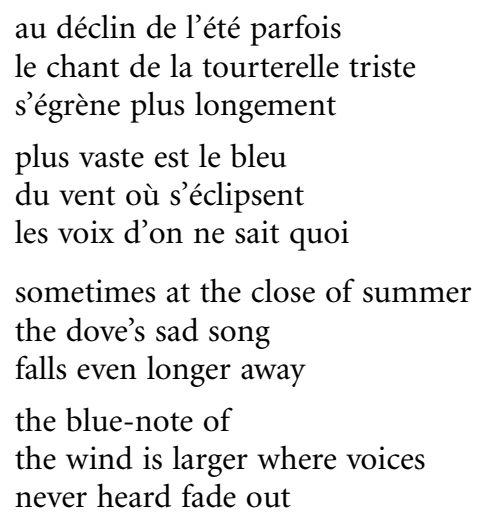

The fusion between the English and French poems is echoed in the water colours by Brault that appear in the book. The thick brushstrokes evoking the forms of birds also have the quality of calligraphy_extending the trope of trans-figuration 
which sustains the poem cycle. Birds/letters write themselves across the ambiguous landscape. The book becomes then a study in trans-formation, showing a series of forms which migrate from one language, one medium, to another.

We recognize in the renga the realization of themes which have long preoccupied Jacques Brault. In Poèmes des quatre côtés he has written compellingly about the interface between creative writing and translation, the relationship to the Other always being at the heart of the poetic experience. But the translation exercise in Poèmes des quatre côtés is framed more as a confrontational experience than the one undertaken here. There Brault speaks of translation as a means of overcoming the sense of cultural inferiorization that he has experienced as a Quebecker. In this friendly dialogue with Blodgett, the antagonistic accents are gone, and the exchange is a dialogue between equals.

\section{The Bridge over the Arno}

Brault and Blodgett's project has distinctly different esthetic finalities from the "comma of translation" in Gail Scott's My Paris. Yet, we can see in both cases the opening of a space of translation which tests the conventional boundaries of interlingual transfer. I would like to suggest that these contemporary practices of translation are realigning territories of cultural difference in Canada, as elsewhere. They do so, I argue, in the name of a new function for translation. Rather than serving as a passage across two discreet cultural zones, translation opens up an intermediate space between them. This space could only be called a bridge if we think of the medieval and Renaissance bridges with their shops and dwellings, the Ponte Vecchio in Florence and the Rialto in Venice.

These are not efficient slabs linking one place with another, spaces whose entire meaning is consumed with the experience of transit. Rather, they are passages cluttered with shops and houses, where entire existences can be spent. These bridges bring duration to the experience of passage. Like Babel, according to Paul Zumthor, ${ }^{7}$ they speak of an experience which is interminable, inachevé. These remnants of the past speak, in unexpected echo, across time.

\section{NOTES}

1. "The comma was just a nuisance. If you got the thing as a whole, the comma kept irritating you all along the line. If you think of a thing as a whole, and the comma keeps sticking out, it gets on your nerves; because, after all, it destroys the reality of the whole. So I got rid more and more of commas. Not because I had any prejudice against commas; but the comma was a stumbling block. When you were conceiving a sentence, the comma stopped you. That is the illustration of the question of grammar and parts of speech, as part of the daily life as we live it." (G. Stein, "How Writing is Written")

2. For remarkable and illuminating commentaries and re-translations of this crucial essay, see TTR, Études sur le texte et ses transformations, "L'essai sur la traduction de Walter Benjamin,” X-2 (1997), sous la direction d'Alexis Nouss.

3. Benjamin's mention of the arcade in this early essay on translation (1923) is prescient because he didn't begin the Arcades project until 1927. For Susan Buck-Morss, "The covered shopping arcades of the nineteenth century were Benjamin's central image because they were the precise material replica of the internal consciousness, or rather, the unconscious of the dreaming collective. All of the errors of bourgeois consciousness could be found there (commodity fetishisms, reificiation, the world as 'inwardness') as well as (in fashion, prostitution, gambling) all of its utopian dreams. 
Moreover, the arcades were the first international style of modern architecture, hence part of the lived experience of a worldwide, metropolitan generation." (Buck-Morss 1989: 38).

4. (Illuminations, W. Benjamin: 79). Or in the new translations by Rendall and Nouss, respectively:

"For the sentence is the wall in front of the language of the original, and word-for-word rendering is the arcade." (TTR, p. 162)

"Car, devant la langue de l'original, la proposition est le mur, la littéralité, l'arcade."

5. See Québec Studies 26, Fall 1998/Winter 1999 for a dossier "Écrire en anglais au Québec: un devenir minoritaire," compiled and edited by Lianne Moyes, with an intervention by Gail Scott.

6. The same could be said for a number of other Montreal poets and novelists who have used translation as an extension of their own literary projects. David Homel's association with Dany Laferrière is a case in point.

7. "L'écriture dès lors est devenir, procès vital, étranger à toute tentative d'identification réaliste, et par définition inachevé: comme Babel, de la même façon que Babel.” (Zumthor 1997: 221)

\section{REFERENCES}

Внавна, Homi (1996): “Unpacking my Library ... Again,” The Post-Colonial Question. Common Skies, Divided Horizons, Iain Chambers and Lidia Curti ed., London and New York, Routledge.

Blodgett, E. D. and Jacques Brault (1999): Transfiguration. Saint-Lambert, Toronto, Editions du Noroît, Buschek Books.

Brault, Jacques (1975): Poèmes des quatre côtés, Saint-Lambert, Editions du Noroît.

Buck-Morss, Susan (1989): The Dialectics of Seeing. Walter Benjamin and the Arcades Project, Cambridge, London, MIT Press.

Burke, Carolyne (1997): Becoming Modern. The Life of Mina Loy, Berkeley, The University of California Press.

Moyes, Lianne (1999): “Écrire en anglais au Québec: un devenir minoritaire," Québec Studies 26, Fall/Winter 1999.

Niranjana, Tejaswini (1992): Siting Translation, Berkeley, University of California Press.

Nouss, Alexis (dir.) (1997): “L'Essai sur la traduction de Walter Benjamin,” numéro spécial de TTR, Etudes sur le texte et ses transformations, X-2.

Scotт, Gail (1999), My Paris, Toronto, The Mercury Press.

Stein, Gertrude, "How Writing is Written."

Théoret, France (1998): Laurence, tr. Gail Scott, Toronto, The Mercury Press, 1998.

Zumthor, Paul (1997): Babel ou l'Inachèvement, "La couleur des idées," Paris, Editions du Seuil. 